\title{
Applied Theatre in Greece: Skipping from Crisis to Crisis
}

\author{
Teatre aplicat a Grècia: sortejar crisis rere crisis
}

El teatro aplicado en Grecia: sorteando crisis tras crisis

Thomai Gkerlektsi. National and Kapodistrian University of Athens (NKUA), Athens, Greece. thgkerle@primedu.uoa.gr

https://orcid.org/0000-0002-5266-3880

\author{
Maria Dimaki-Zora. National and Kapodistrian University of Athens (NKUA), Athens, \\ Greece,mzora@primedu.uoa.gr \\ https://orcid.org/0000-0003-0902-5338
}

\begin{abstract}
This paper explores the emergence of applied and online theatre in Greece. The authors present the appearance of the term "Applied Theatre" in the Greek literature as well as three examples of "applied theatre praxis". These applied theatre practices have been implemented in various contexts by different agencies during the country's recent debt crisis. Moreover, online theatre is being discussed as a spontaneous reaction of theatre industry to health crisis caused by the expansion of COVID-19 virus. The paper raises concerns on theatre's standing in the post pandemic era, focusing on theatre's potential in times of social, political and economic adversity.
\end{abstract}

Keywords: applied theatre, online theatre, debt crisis, health crisis

\section{Resum}

Aquest article explora l'aparició del teatre en línia i aplicat a Grècia. L'autor i l'autora presenten el sorgiment del terme Teatre Aplicat a la literatura grega i també tres exemples de pràctica de teatre aplicat. Aquestes pràctiques de teatre aplicat han sigut implementades en diversos contextos per diferents agències durant la recent crisi de deute al país. A més a més, el teatre online es considera com a una reacció espontània de la indústria del teatre a la crisi sanitària causada per l'expansió del virus Covid-19. L'article expressa les preocupacions al voltant de la posició del teatre en l'era postpandèmia, i focalitza al potencial del teatre en temps d'adversitat social, política i econòmica.

Paraules clau: teatre aplicat, teatre en línia, crisi de deute, crisi sanitària

\section{Resumen}

Este artículo explora el surgimiento del teatro en línea y aplicado en Grecia. El autor y la autora presentan la aparición del término Teatro Aplicado en la literatura griega y también tres ejemplos de práctica de teatro aplicado. Estas prácticas de teatro aplicado han sido implementadas en diversos contextos por diferentes agencias durante la reciente crisis de deuda en el país. Además, el teatro en línea es considera como una 
reacción espontánea de la industria del teatro a la crisis sanitaria causada por la expansión del virus Covid19. El articulo expresa las preocupaciones acerca de la posición del teatro en la era pospandemia y focaliza en el potencial del teatro en tiempo de adversidad social, política y económica.

Palabras clave: teatro aplicado, teatro en línea, crisis de deuda, crisis sanitaria

\section{Introduction}

Arguing that during the last decade Greek society went through one of its most difficult periods since the establishment of the modern Greek state, would be neither irrational nor an excess. This research concerns theatrical activity during the Greek economic crisis. Theatre is supposed to be a superior artistic genre, which creatively integrates other arts (Patsalidis, 2013). It is also considered as an important socializing agent from the ancient era up to our days, which listens and reflects the social reality of its time (Goldhill, 2007; Pfister, 1988)

Before exploring theatre in crisis, a brief reference to the crisis itself and its characteristics would be useful. An influx of refugees and immigrants in the country, in addition to mass outflow of skilled local workers and scientists into more robust western economies, the so-called 'brain drain', gave new social and political dimensions to the national economic crisis during 2008-2018. Citizens witnessed growth of depression, poverty and xenophobia along with a growing number of new taxes, homeless people, firings and suicides (Hardouvelis, 2018; Matsagkanis 2013; Sanders IV, 2018; Smith 2017).

These circumstances could explain the catholic mistrust in politics, articulated by the Indignant movement in a series of demonstrations (Avgeropoulos, 2015; Sanders IV, 2018). The above could also explain the unfortunate rising of the Golden Dawn, a Greek fascist political party. In 2010, a low-income majority, struggling to survive on the one hand and a privileged minority on the other, unaffected by the crisis continuing to increase its wealth and prosperity, comprised Greek society according to a Eurobarometer survey (Bogiopoulos, 2011).

Pammenter and Prentki (2014) consider the Greek crisis, like many other similar crises, a structural component of capitalism, created in order to transfer bank and business debts to people as well as to justify decrease of public goods, such as public health and education. In this context it gets even more difficult for theatre to be established and prosper in educational settings than it is in times of economic, political and social stability. Grammatas (2014) places the Greek crisis in the context of a wider WestEast economic conflict, which takes place in a globalized capitalist society that promotes xenophobia, defies ecology and deifies technocracy. As a solution to this problem, which influences our value 
system in a negative way and tends to take on "human crisis" dimensions, he proposes the immediate shift of the Educational Systems to a "New Humanism", in which theatre plays an important role. After all, theatre and drama in education are related to holistic human development (Papadopoulos, 2010).

Even though it sounds seemingly odd, art flourished during the crisis and Greek artists proved to be unexpectedly creative, defying a declining economy, austerity measures, high unemployment rates and capital controls (Tziovas, 2017). Believing in art's social potential, they overcame the harsh funding conditions and used their art as a means of promoting dialog, political reflection and social claims (Kaldi,

Theatre artists used their talent in order to expose the collective and individual decline, as well as to investigate the causes and results of the crisis.

2013; Papaspyrou and Patroni, 2014; Zervou, 2017). In this unforgiving climate, Greek theatre gained in diversity and experimentation and it paradoxically became more affordable (Dimaki-Zora, 2020).

Theatre is inherently political (Esslin, 1976; Boal, 1981). Politics always lurks in theatre, especially in certain types of it, albeit a gradual surrender to commercialism and individualism is evident since the last quarter of the 20th century (Pefanis, 2003). Applied theatre could be regarded as one of the most political modern theatrical approaches, since it draws its ideas and practices from the post-World War II educational and artistic progressive movements (Neelands, 2007; Nicholson, 2005; Prendergast and Saxton, 2009; Prentki and Preston, 2009). More precisely, applied theatre encompasses participation and transformation (Ackroyd, 2000) and it is closely related to democratic practice and active citizenship under certain conditions (Prendergast and Saxton, 2009).

It would therefore be rather unexpected from the Greek nation that pioneered in the foundations of democracy and modern west theatre (Allardyce, 1981; Hartnoll, 1980; Wilcken, 1976; History of Greek Nation, 1972), to stay unaffected by these radical theatrical shifts. After investigating the appearance of the term applied theatre in Greek academia and literature, we will present three applied theatre case studies that took place in Greece during the country's debt crisis.

\section{Applied Theatre in Academia \& Praxis}

\subsection{Applied Theatre in Academia}

As indicated by Ackroyd (2000), Nicholson (2005), Thompson (2003), Prendergast \& Saxton (2009), Prentki \& Preston (2009) et al., applied theatre practice emerged before the akin theory. Long before the terms Applied Theatre/Drama/Performance were born in Anglo-Saxon scholarship by academics, 
numerous theatre practitioners were already working on settings and methods described by these terms. As Taylor points out:

\begin{abstract}
Applied theatre became a particularly useful description given that it encompasses the breadth of work that theatre programs were creating inside and outside of educational settings, mostly in nontheatrical environments for different purposes-raising awareness, posing alternatives, healing psychological wounds or barriers, challenging contemporary discourses, voicing the views of the silent and marginal. (Taylor, 2003, p. xxi)
\end{abstract}

Respectively, the term "applied theatre" was introduced to the Greek literature in the first years of 21st century and there is still limited theoretical documentation related to it, whereas applied theatre practice began almost a decade earlier. So far, the translation of Christopher Balme's book 'The Cambridge Introduction to Theatre Studies' by Romanos Kokkinakis and Vicky Liakopoulou (2012) remains a basic source of information about applied theatre, written in the Greek language.

The first Greek scholar and theatre practitioner who wrote about applied theatre is Christina Zoniou (2007). She defines it as a non-professional theatre species, which shapes its identity through its intention, venue, target group and process-based rather than product-based methods. She proceeds to her own distinction of applied theatre in: a) social theatre, b) performing arts in education and c) therapeutic theatre. Social theatre focuses on activism, social transformation, adult education and intercultural education. Performing arts in education concern the use of theatre practices in formal or non-formal educational contexts. Finally, therapeutic theater uses a variety of theatre techniques for psychotherapeutic purposes (Zoniou, 2016).

The wide range of applied theatre is also pointed out by Persephone Sextou, one of the first academics who empowered health education TiE programs in Greece. In a paper which describes one of those health education programs, Sextou and Hatzinikolaou (2007) add TiE and DiE in the portmanteau of applied drama/theatre alongside with theatre in health education, prison theatre, theatre for development, heritage theatre, community theatre, reminiscence theatre and theatre in business settings.

Approaching Zoniou's first two applied theatre categories, Fanouraki (2010) sees community theatre as part of applied theatre and highlights its focus on marginalized social groups, sociopolitical dimension and transformative potential. She also regards Theatre in Education (TiE) as part of this community-based theatre tradition. 
While applied theatre is usually suggested as an umbrella term that includes TiE and DiE, Papadopoulos (2014) implies that applied drama is part of TiE and DiE when he

Despite the differences in every scholar's approach, the previous views lead to the common conclusion that applied theatre has a strong connection with education. refers to it as one among various methods, which the wider field of educational drama makes use of. He mentions John Somers' practice as a connection between educational theatre/drama and applied theatre/drama.

Furthermore, Avra Avdi (2011) reviewed Helen Nicholson's book Applied Drama; The Gift of Theatre for the Education and Theater Magazine. In 2014, Dave Pammenter's and Tim Prentki's announcement on the $7^{\text {th }}$ International Conference on Theatre in Education Bonds of solidarity (Athens, 23-25 November, 2012) was translated in Greek by Betty Giannouli and Myrto Pigou-Repousi and published in the same magazine. The authors emphasize the restrictions, limits and dangers of using applied theatre within a capitalistic framework, while at the same time they are enthusiastic about applied theatre projects which aim to overthrow this framework. They also analyze the use of applied theatre for personal, social and political change and recommend that practitioners and participants should give priority to sociopolitical intervention (Pammenter \& Prentki, 2014).

Whatever the terms Applied Theatre/Drama/Performance indicate in British, North American and Australian contexts, in Mediterranean and Latin American Theatre Studies, they are referred as 'Social Theatre' (Bernardi and Malini, 2017, Pagnes 2019, Thompson and Schechner, 2004). Apparently, Greece follows this tradition, too. The National Theatre of Greece, the most important state theatre of the country, officially names its cooperation with special social groups in unconventional settings



In recent years though, there has been a growing research interest in the field of applied theatre, probably explained by the hesitant and fragmentary entering of the term in Greek higher education institutions. 
Documentations of this interest are mainly traced in master dissertations conducted in Theatre

The term 'social theatre' seems to prevail in Greek academia, but what is more important than terminology, is the growing social engagement of theatre studies and their adaptation to the interests of applied theater.
Departments of the country's universities (Lyra 2015, Angeli 2019, Samara 2020, Stamati 2019 and Vasileiadou 2012) rather than in the universities' curriculum. Our research led to the conclusion that only two institutions, National and Kapodistrian University of Athens (NKUA) and Aristotle University of Thessaloniki (AUTH), mention the term "Applied Theatre" in their Study Guides: Katerina Diakoumopoulou teaches 'Applied Theatre' in the postgraduate program of the NKUA and Myrto Pigou-Repousi teaches 'Special issues of applied theater: theater and youth culture in the public space' in the postgraduate program of AUTH.

The term 'social theatre' seems to prevail in Greek academia, but what is more important than terminology, is the growing social engagement of theatre studies and their adaptation to the interests of applied theater.

\subsection{Applied Theatre Praxis}

It is worth mentioning that the related praxis has been varied and vigorous but before proceeding to our analysis of Greek applied theatre praxis, it is worth explaining why we prefer to use the term praxis rather than practice. Paulo Freire invented this notion as a way to combine theory and practice in a fruitful way and to reduce divisions between 'thinkers' and 'doers' (Taylor, 2003). That is why we agree with Taylor when he says:

\footnotetext{
Praxis is powered by an agenda, a desire to push us to reflect on our practices and refine our theoretical leanings as a step toward acting on and changing our life circumstances. Put simply, praxis denotes the action, reflection, and transformation of people as they engage with one another. Those involved in praxis can anticipate that such action, reflection and transformation should help people create a just and better world. And, this is where applied theatre can play a major role. (Taylor, 2003, p.35)
}

From the late 80 s to the early $00 \mathrm{~s}$, some radical changes promoted the relocation and reconsideration of theatre in education in Greece (Kladaki, 2010). The first steps were made in 1989 and 1990, when

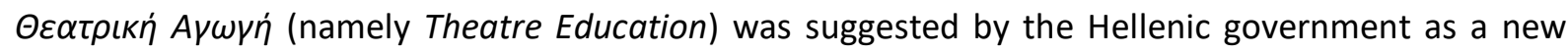
addition to the Hellenic National Curriculum (NC) (HELLENIC MINISTRY OF EDUCATION \& RELIGIOUS AFFAIRS 1989, 1990). In the following years, publication of a teacher's textbook on Theatre Education and reinforcement of drama teacher training by the Hellenic Ministry of Education and Religious Affairs (HMERA) and the Hellenic Departments of Education or/and Drama, supported the integration of 
drama and theatre in the National Educational System (Sextou, 2002). Furthermore, a cooperation between HMERA, HMC (Hellenic Ministry of Culture) and Boards of Education called Melina Program: Education and Culture was the first large-scale and long-term national project towards investigating the role of arts within the formal education system. At the end of the $20^{\text {th }}$ century and the beginning of the $21^{\text {st }}$, innovations of great importance strengthened theatre's shift from its conventional settings; The informal constitution of the Hellenic Theatre/Drama \& Education Network, an association for the promotion of research on and practice of theatre, educational drama and other performing arts within formal and non-formal education, as well as the conduction of the first conferences on educational drama (Sakellariou, 2015).

In the second decade of the 00s, applied theatre initiatives reached their peak. Some of the most important and popular Greek theatre stages like National Theatre of Greece, National Theatre of Northern Greece, Municipal Theatre of Piraeus, New World Theatre, Art Theatre (Theatro Technis Karolos Koun) and Onassis Stegi, inaugurated a series of social actions for special target groups like children, adolescents, the elderly, prisoners, refugees, LGTBIQ community and more. These actions are presented on the theatre companies' websites ${ }^{1} . \ln 2013$, the first meeting of Greek Theatre of the Oppressed Activist Groups was held (Boemi, 2014). Plenty of applied theatre projects were designed and implemented during the crisis by theatre groups, in cooperation with state services and various non-profit organizations. For example, ActionAid Hellas and the UNHCR Greece made a significant contribution to raising the awareness of Greeks on refugee issues by funding and designing correspondent performances, theatre workshops and facilitator's handbooks (UNHCR Greece, 2013, 2014).

\subsection{Applied Theatre in Practice. Some Examples}

Three applied theatre projects that took place in the formerly described era of social instability are presented here. Despite the different contexts of the following projects, all of them are nonprofit and include a performance. The first one is a short-term Prison Theatre intervention by the Hellenic Theatre/Drama \& Education Network (TENet-Gr). Then, we will discuss how a long-term collaboration between nursing homes and Seveneleven Theatre Company accentuated Reminiscence Theatre in Greece. The last example displays the most abiding domestic example of Theatre in Hospitals, set up by the New World Theatre.

\footnotetext{
1 Information about Greek Theatre Companies' applied theatre practices, available on the websites: https://www.n-t.gr/en/ (National Theatre of Greece), https://www.ntng.gr/default.aspx?lang=en-GB\&page=1 (National Theatre of Northern Greece), https://www.theatro-technis.gr/en/ (Art Theatre), https://www.dithepi.gr/en/ (Municipal Theatre of Piraeus), https://nkt.gr/ (The New World Theatre), https://www.onassis.org/onassis-stegi (Onassis Stegi).
} 
There are different reasons why we chose to expound these projects as representative of the local applied theatre praxis. Among our criteria for selection, we should mention the engagement of these projects in a wide range of vulnerable groups, the discrepancy between their purpose, methods, duration, location and funding sources, as well as the originality of their agents. More specifically, TENet-Gr is the most remarkable representative of what we previously mentioned as performing arts in education according to Zoniou (2016). It operates in a variety of settings throughout the country and abroad, using drama as a powerful means of communication and learning. Thanks to its workshops, seminars, annual journal and updated website, which offers a brief overview of domestic developments in the prison theater sector, TENet-Gr helps both practitioners and researchers. Seveneleven can be proud of the most methodical and painstaking approach to theatre for the elderly, considering that their process has transcended the level of mere entertainment and ended up as one of the infrequent pieces of local reminiscence theatre. The New World Theatre, a mainstream theatre in Athens, inaugurated theatre in hospitals when the rest of conventional theatre stages of the country were still too busy with aesthetics and/or commercialism. After years of steadfast commitment, its team of dedicated artists managed to gain expertise and to expand their innovation.

\subsubsection{Prison Theatre: Roles in Life - Roles in the Theatre}

Prison theatre and Theatre of the Oppressed lie at the core of applied theatre practice and research (Nicholson, 2005; Prendergast and Saxton, 2009; Thompson, 2003). These theatre types are welcome by those who belong in the radical movement of Critical Education, because Critical Education is committed to forms of learning and action carried out in solidarity with subordinate and marginalized groups (McLaren, 2010).

Applied theatre practitioners around the world cooperate with some of the most oppressed and marginalized citizens such us prisoners, using Boal's method which is inspired by the Freirian vision of a world without oppression, a world that would treat all the people equally:

[...]The oppressed are considered pathological cases of a healthy society, which must therefore adapt these "incompetent and lazy" to its own molds, changing their mentality. These marginalized people need to be "integrated" into the healthy society they have "denied". The truth is, however, that the oppressed are not marginalized people living "outside" society. They were always inside the very structure of society, which turned them into "beings for others"... (Freire, 1977, p.81)

The Hellenic Theatre/Drama \& Education Network (http://theatroedu.gr/) is a non-profit association and scientific organization, whose members are volunteers. Since its informal establishment in 1998 until today, it is responsible for many novelties, as for instance the publication of Education and 
Theater Magazine, the arrangement of theater conferences, workshops and training seminars for theatre educators, students, teachers, facilitators and marginal social groups. The workshops usually use drama in order to encourage literacy, creativity, conflict resolution and elimination of stereotypes about urgent issues such as immigration, addiction and offense. TENet-Gr is a principal exponent of what we could call Greek applied theatre.

Invited by the School Principal of the Second Chance School (SCS) operating in the men's prison of Korydallos, TENet-Gr designed and implemented a project entitled 'Roles in life-roles in the theater' during the school year 2016-2017. Three members of the TENet-Gr facilitated the project; actress and facilitator of youth theatre groups Irini Koumbarouli, theatrologist and theatre-pedagogue Sonia Mologousi and sociologist and theatre-pedagogue Hara Tsoukala. They held twenty-two two-hour drama workshops from 17th of January through the $28^{\text {th }}$ of June with fifteen adult male detainees. They used improvisation, devised theatre, educational drama and physical theatre in order to explore:

- Different and often controversial roles each member of the society is called to perform on a daily basis and problems arising from this multitasking effort.

- Whether it is possible or impossible for human beings to communicate effectively with each other.

- How can individuals re-approach their imagination and worldview.

The team concluded this collaboration with the theatrical event Poteflas ore... Poteflas, a performance with references to S. Beckett's Waiting for Godot. The performance took place at the SCS on $27^{\text {th }}$ and $28^{\text {th }}$ of June. It was presented to representatives of state institutions, teachers and students of the school $^{2}$.

\subsubsection{Reminiscence Theatre: How did Violas and Hyacinths bloom?}

In 2013 two actors, Notis Paraskevopoulos and Konstantina Maltezou, founded the Seveneleven Theater Company motivated by the desire to make theatre according to their own aesthetics and philosophy and to use arts as a tool for achieving individual and social prosperity. Soon, the elderly attracted their artistic interest.

The company is mainly funded by charities and secondarily by its own theatrical productions and various art classes for children and adults. Paraskevopoulos, Maltezou and their volunteer partners apply a distinctive entertainment model to nursing home dwellers. This project started in 2014 , when the company was involved in the pilot charity program Adama, launched by the Synthesis Culture

\footnotetext{
${ }^{2}$ From a telephone interview with Hara Tsoukala to the writers, on 19.11.2020.
} 
Company and funded by the TIMA Charitable Foundation. The country was facing a financial hardship and the elderly were noticeably neglected, when Seveneleven participated in the program. According to Paraskevopoulos, Seveneleven became the most important external factor of the time to undertake interventions of recreational participatory actions in Greek nursing homes. Adama project was based on a recognized British model of entertainment and sought the mental empowerment of the elderly, beyond entertainment.

Experience gained from nursing home visits combined with research and study on health problems and characteristics of the elderly as a distinct social group, resulted in the abandonment of the original model and the development of an alternative standard method of communication and entertainment for the elderly with dementia. This is the 'thallo method', based on the 'principle of associative thinking'.

The name of the method comes from the ancient Greek verb $\theta \alpha \dot{\lambda} \lambda \omega \omega$ that means flourish It is applied by volunteers, specially trained in using theatre as a means of enhancing human self-confidence, imagination and initiative. Each session with the seniors includes games, sensory integration activities, practices such as the 'isolated listening' and other techniques, which are analyzed in Paraskevopoulos' unreleased edition 365 Days Next to the Third Age. Thallo method embraces mental and emotional empowerment of the elderly, a social group seriously affected by the economic crisis (Tima Charitable Foundation, 2020) and attempts to raise awareness on the degenerative brain diseases. The method ended up in a namesake project which started in 2018 thanks to a donation of Stavros Niarchos Foundation. The donation allowed the expansion of the project to a great deal of nursing homes in Attica. Before the government's recent (March, 2020) decision to take restrictive measures against COVID-19, thallo was also implemented in Chios, Arta and Konitsa, while it intended to spread to other places of the country.

The highlight of the project was the reminiscence theatre piece Violas and Hyacinths, based on autobiographical testimonies of people with dementia, hosted in the nursing homes that participated in thallo. Violas and Hyacinths is the title of an old Greek song that is proved to be among the most popular in the seniors, functioning as a reference point in their memory. The play was performed in 2018-2019 at Thision, a mainstream theatre in Athens. The aim of the performance was to raise sympathy for the elderly and to convince people to stay alert on degenerative brain diseases and diseases related to ageing ${ }^{3}$.

\subsubsection{Theatre in Hospitals: Performing Solidarity}

\footnotetext{
${ }^{3}$ From a live interview with Notis Paraskevopoulos to the writers, on 12.02.2020. For more information on the subject: www.seveneleven.me
} 
According to Article 27 of the Universal Declaration of Human Rights "Everyone has the right freely to participate in the cultural life of the community, to enjoy the arts and to share in scientific advancement and its benefits" (United Nations General Assembly, 1948). Nevertheless, sick people and especially children are often intentionally or unintentionally excluded from social and cultural life, possibly because our globalizing culture does not embrace loss or death. Pedagogy of Loss/Death intends to familiarize human beings with concepts like end, mortality, fragility, to teach them how to develop empathy and care for the natural world or how to deal with the trauma of a sudden death (Affifi and Christie 2019, Rodriguez; De la Herran \& Cortina, 2019). Arts education seems to be an effective tool for the exploration of death and loss (Affifi and Christie, 2019). Luckily, applied theatre places theatre in hospitals and theatre for health education in its principal repertoire (Prendergast and Saxton, 2009).

The New World Theatre is a unique case of Greek professional theater that, for eighteen consecutive years, has carried out charitable work with the label 'Solidarity Theatre for Children' (Papalexi, 2018). In 2002, artistic director Vangelis Theodoropoulos, decided to create an itinerant theatre troupe for children in hospitals.

Since then, the troupe has been conducting daily visits and performances to hospitals, institutions and other places with disadvantaged children. Solidarity Theatre for Children has so far performed for children, parents, nursing staff, teachers and other employees. It has operated in different settings of Attica, as for instance in hospitals (Aglaia Kyriakou, Paidon Agia Sofia, Paidon Pentelis), degraded schools, squares and refugee camps. The project has also expanded in the women's prison of Thebes, as also in Thessaloniki and Cyprus in collaboration with Doctors of the World. All these years the team created twelve different theatre pieces. Some of them are based on classic fairy tales such as Pinocchio while most of them, like the theatre piece It's dawning by Maria Papalexi, were created entirely for this purpose.

The members of the itinerary troupe have changed over the years but the project so far counts more than 2,000 performances. These productions are free for the audience but the actors are normally paid. Therefore, New World Theatre is constantly looking for sponsors. Until now, the Solidarity Theatre for Children initiative has been funded by public and private bodies, such as Municipality of Athens, Attica Region, Onassis Foundation, Stavros Niarchos Foundation, COSMOTE (Telecommunications Company), ELPEDISON (Energy Supply Company) and so on. Maria Papalexi, key executive of New World Theater, quotes a memorable moment of the project: 
..we were performing in a chamber only for one child who was in the final stage of a serious illness. Although the child had lately quitted talking, he reacted to the performance, he laughed. Unfortunately, it was just a flash.. ${ }^{4}$

\section{Online Theatre: A Trend or a Rule?}

As soon as the economic crisis came to an end according to the majority of financial analysts, in reality it was replaced by a new, more expansive and uncontrollable one. In 2020, the spread of the COVID19 virus and subsequent global pandemic, threatened the global health system. From the beginning of 2020 and afterwards, several states, including Greece, imposed a strict quarantine. With a few exceptions, citizens were obliged to minimize transits and gatherings, by staying in and working from home. Educational and cultural institutions, sports centers, tourist facilities and other parts of everyday life remained inaccessible for months, leading people to unprecedented perplexity and many workers to insecurity and financial hardship that could possibly turn into a new financial crisis. To make matters worse, humanity has not yet overcome coronavirus turbulence and confronts newly imposed lockdowns. This situation certainly raises questions and concerns about theatre in the coronavirus and post-coronavirus era (Patsalidis, 2020).

Online theatre, that is to say the possibility to watch free or priced performances from your screen, is the up to now spontaneous response of the theatre industry (Timplalexi, 2020). The fact that digital technology has irrevocably invaded arts is already admitted (Davis, 2012; Grammatas, 2015) but the international online streaming campaign throughout the lockdown is something completely new. Prominent stages like British National Theatre and Globe Theatre, the French Théâtre du Soleil and the German Schaubühne made part of their digital archive available online (Karaoglou, 2020).

Many Greek theatres endorsed this tendency and became equally inventive. Karolos Koun Art Theater was the first company to announce the release of web and audio performances for the 2020-2021 theatre season (Kriou, 2020). Through its online platform Remote Art Theatre, the company managed to ensure communication with its audience. In the meantime, many artists and theatre companies adopted similar methods, as for instance Nickolas Androulakis and Elli Papakonstantinou, the directors of the live streaming online performances Dämmerung and Trace of Antigone (Kriou and Karaoglou, 2020).

Furthermore, ENTER by Onassis Foundation, Forced memories by Emmanouela Vogiatzaki Krukowski, teaching staff of Department of Theater Studies - University of Peloponnese and The Quarantine

\footnotetext{
${ }^{4}$ From a telephone interview with Maria Papalexi to the writers, on 25.01.2020. For more information: www.nkt.gr
} 
Monologues by UNHCR Greece and TENet-Gr are three projects that triggered artistic expression and creativity throughout the lockdown situation. The first project consists of original artworks, created within 120 hours under the most eccentric circumstances. Artists, invited by Onassis Foundation to preserve the memories of the lockdown condition, based their work on their houses, relatives, friends and objects and shared their productions through a digital platform. In forced memories international artists inspired by Samuel Beckett's bizarre characters, took part in a tele-video-performance, so as to share their COVID-era feelings and memories and envision the post-COVID humanity. From April to May 2020, a group of adolescent refugees participated in a series of online creative writing workshops. The workshops resulted in The Quarantine Monologues, a publication which illustrates health crisis' impact on the young authors.

Another effort has been recently carried out by Poreia Theater. Its instigator, artistic director of Poreia Theater, Dimitris Tarlow, names his idea 'cinematic theatre' and proposes it as a way to protect theatre workers from unemployment during the pandemic. What is more, this new kind of theatre is supposed to help disadvantaged people, isolated communities and foreign art lovers gain access to the contemporary Greek theatrical creation. Tarlow explains with optimism:

In this difficult and critical time, we choose to raise the bar even higher. Having worked intensively for the last six months, we are ready for another premiere, our first online realtime live streaming, with six cameras, on-site telescoping and you spectators in the auditorium. This effort is coming to create a new genre: the cinematic theater. Through this, Poreia Theater will be able to reach all the houses, in all corners of Greece, even the most remote ones, to educate and entertain, to entertain and comfort. (Tarlow, 28/09/2020)

\section{Conclusion}

On-line communication and on-line education have been vital aspects of our everyday life since the 80 's (Vosniadou 2006) creating new prospects for learning and relationship building. Flexibility, speed and convenience make on-line communication and education appealing but certain disadvantages are also related to them, such as health problems, unequal access to computers, GDPR issues, isolation and distraction from meaning and purpose (Newby et al., 2009; Kalligeri, 2011; Gordes \& Millez, 2011; Didi, 2011). What about on-line theatre?

A positive aspect of the above mentioned modifications is that they inform us about theatre's strong influence on human life. Fortunately, theatre gives the impression of being something superior to a popular hobby. 
As the high online theatre viewing rates indicate (Karaoglou, 2020), people supported theatre in these difficult times not only because of their facilitated access to it, but also because they were looking for a mental escape in theatre's 'as if' condition (Schechner, 2011, 22-23), imaginary freedom, enigmatic atmosphere and therapeutic effect. A further advantage of online theatre, is the opportunity it gives to local theatre artists to broaden their audiences and make their work worldwide recognizable. Creators are forced to stay alert and search for low-cost solutions without settling for aesthetic deficit.

Let us not forget though, that these positive aspects only concern independent artists and a minority of theatre owners that can afford the technological equipment which is going to ensure their entrance to the online theatre reality. Theatre in our globalized neoliberal world depends more than ever on the rules of global market and this is the reason why it frequently adapts to the requirements of the social media and commercialism (Tzamargias, 2010). The majority of theatre stages, especially the unconventional and inquiry ones, that usually do not enjoy state or charitable fund, will probably be unable to cover their operating expenses. Without proper state support, the theatre world faces the danger of artistic lethargy and social turbulence. Support Art Workers initiative appeared in the pandemic, as a spontaneous reaction to the chronic devaluation of art workers in Greece. Members and allies of the initiative asked for governmental support and protested against the upcoming risk of unemployment and poverty, in case of an extended lockdown.

Perhaps the most worrying things regarding online theatre are the inevitable one-way direction from theatre scene to the distanced spectator(s) and the end of the ephemeral nature of the theatrical event. Deprived from its rituals, without feedback from the audience and the sense of here and now, theatrical experience may result in stagnation. Communication and interaction are theatre's cornerstones, especially when we talk about participatory, socially and politically engaged theatre practices like applied theatre.

In violent times like the current ones, radical theatre is harder but also more necessary to find. In this new context, applied theatre's next steps are crucial. Taking into account that coronavirus is still threatening our everyday life and Europe will probably experience new lockdown-waves, applied theatre should reassess its target groups and locations. At the same time, there is an urgent need for a fruitful connection between academia and praxis. Theatre studies should deepen applied theatre research and increase the number of applied theatre projects.

Applied theatre projects could emphasize on helping pupils and students join their coronavirusaffected educational system. They could also negotiate the contemporary struggle of doctors, nurses and other health care workers and could focus their attention to the families and friends of COVID-19 victims. 
Finally, we should always keep in mind that homeless people, the elderly, drug addicts and other social victims are still out there, suffering from an older disease, our ignorance. We are witnessing a growing inclination for remote work, remote gymnastics, remote shopping and remote entertainment. If we add remote art to this list, then we run the risk of basing our future on individualism, isolation and loneliness. Technology is absolutely not to blame. But we have to agree with the quote that theatre is and should remain 'the art of the sweaty face and the stretched body' (Pefanis, 2003, 39).

\section{References}

Ackroyd, J. (2000). Applied Theatre: Problems and Possibilities. Applied Theatre Researcher, 1. https://www.intellectbooks.com/asset/755/atr-1.1-ackroyd.pdf.

Affifi, R. \& Christie, B. (2019). Facing loss: Pedagogy of death, Environmental Education Research, 25(8), $1143-$ 1157. https://doi.org/10.1080/13504622.2018.1446511.

Angeli, N. (2019). Applied theatre practices aiming at raising children and teacher awareness on human rights. Case study: the theatrical pedagogical program "what if it was you?" [Master thesis]. Pergamos collection. https://pergamos.lib.uoa.gr/uoa/dl/object/2849956

Allardyce, N. (1981). World Drama: from Aeschylus to Anouilh Vol.1 (M. Oikonomou trans.). Smirniotis. (original edition 1949).

Andriotis, N., Andronikos, M., Atsalos, V., Georgiadis, T., Despotopoulos, A., Dimakis, P., ... Hourmouziadis, N. (1972). History of the Greek Nation, Vol.3a. Ekdotiki Athinon.

Avdi, A. (2011). Book Review. Helen Nicholson: Applied Drama; The Gift of Theatre. Education \& Theatre Magazine, 12, 84-85.

Avgeropoulos, Y. (2015). Agora-From Democracy to the Market (documentary). Small Planet Productions.

Balme, B. C. (2012). The Cambridge Introduction to Theatre Studies. (R. Kokkinakis \& V. Liakopoulou trans.). Plethron.

Bernardi, C. \& Malini, G. I. (2017). Performare la societas. Le intersezioni del teatro sociale e della performance nella riflessione e prassi contemporanee. In C. H. Cruz Hug, B. I.Bezelga Isabe \& R. P. S. Rodrigues Paulo Simõe (Eds.), Práticas Artísticas Comunitárias (pp. 54- 68). PELE - Espaço de Contacto Social e Cultural; CHAIA - Centro de História da Arte e Investigação Artística da Universidade de Évora; FCT - Fundação para a Ciência e a Tecnologia. http://hdl.handle.net/10807/159062

Boal, A. (1981). Theatre of the Oppressed. (E. Braoudaki trans.). Theoria. (original edition 1974).

Boemi, N. (2014). 'Take ..Forum and run!' - a report on the $1^{\text {st }}$ National Camping for Theatre of the Oppressed Groups in Greece (6-8/9/2013). Education \& Theatre Magazine 15: 65-73.

Bogiopoulos, N. (2011). Is capitalism, stupid. The perpetrators of the crisis and the 'debt' of their overturn - a kind answer to the preatrians of the memorandums. Livani.

Davis, S. (2012). Liveness, mediation and immediacy -innovative technology use in process and performance. RiDE: The Journal of Applied Theatre and Performance, 17(4), 501-516. https://doi.org/10.1080/13569783.2012.727623.

Didi, L. (2011). On the introduction of PC in schools. Themata Paideias, 11(43-44), 15-17.

Dimaki-Zora, M. (2020). Aspects, representations, refractions of the economic crisis in Modern Greek Drama. In V. Sabatakakis, (Ed.), The Greek World in Periods of Crisis and Recovery, 1204-2018, Vol. 5, (pp. 421-436). European Society of Modern Greek Studies. https://www.eens.org/wordpress/wpcontent/uploads/2020/11/tomos5.pdf 
Esslin, M. (1976). Anatomy of Drama. Hill and Wang.

Fanouraki, K. (2010). The teaching of the philological subjects through theatre education in secondary education. [Doctoral dissertation, University of Patras].

https://thesis.ekt.gr/thesisBookReader/id/19219\#page/1/mode/2up.

Freire, P. (1977). Pedagogy of the Oppressed. Kedros.

Goldhill, S. (2007). The audience of the Athenian tragedy. In P.E. Easterling (Ed.), The Cambridge Companion to Greek Tragedy, (L. Rozi and K. Valakas trans,) (pp. 81-101). University Press.

Gordes, C. and Millez, E. (2011). The dangers of using computers in childhood. Themata Paideias, 11(43-44), 2146.

Grammatas, Th. (2014). Pammousos Pedagogy. In Th. Grammatas (Ed.), Theater in Education. Artistic Expression and Pedagogy. Diadrasi. (pp. 71-84).

Grammatas, Th. (2015). Theatre as a cultural phenomenon. Papazisis.

Hardouvelis, A. (2018). The seal of Lehman in the ten-year Greek adventure. Ta Nea. https://www.tanea.gr/print/2018/09/15/opinions/i-sfragida-tis-lehman-crsti-dekaeti-elliniki-peripeteia/

Hartnoll, Ph. (1980). A concise history of the theatre. (R. Pateraki trans.). Ipodomi. (original edition 1968).

Hellenic Ministry of Education \& Religious Affairs (1989) Presidential Decree for Pre-School Education, P.D. 486/1989-F.E.K. 208 A (Athens).

Hellenic Ministry of Education \& Religious Affairs (1990) Presidential Decree for Primary Education, P.D. 132/1990-F.E.K. 53 A (Athens).

Kaldi, M. (2013). Garbage-A play on the economic crisis. Education \& Theatre Journal, 14, 121-126.

Kalligeri, M. (2011). Scientists are ringing the bell for the use of computer by children. Themata Paideias, 11(4344), 18-20.

Karaoglou, T. (2020). The lessons we learned from online theatre. Athinorama. https://www.athinorama.gr/theatre/article/ti_mathame_telika_apo_tis_online_parastaseis-2541725.html.

Kladaki, M. (2010). 1900-2000: 100 years of Children's Theatre in Greece. Education \& Theatre Journal, 11, 713.

Kriou, M. (2020). The first online premieres are coming soon. Athinorama. https://www.athinorama.gr/theatre/article/oi_protes_diadiktuakes_premieres_einai_edo-2545021.html.

Kriou, M. and Karaoglou, T. (2020). Digital Theatre: Is this the beginning of a new art genre? Interview with Savvas Patsalidis. Athinorama. https://www.athinorama.gr/theatre/article/psifiako_theatro_mia_nea_texni_gennietai-2541840.html.

Lyra, Z. (2015). Trojan Horse: applied theatre in prison to addicted offenders, attending the addiction recovery program KETHEA PROMETHEUS, [Master thesis, AUTH]. AUTH IKEE collection. http://ikee.lib.auth.gr/record/270733/files/GRI-2015-14900.pdf).

Matsaganis, M. (2013). The Greek Crisis: Social Impact and Policy Responses, Friedrich-Ebert-Stiftung. http://library.fes.de/pdf-files/id/10314.pdf

McLaren, P. (2010). Critical Education. An Overview. In (P. Gounari \& G. Grollios Ed.) Critical Education. A collection of texts, 279-330. Gutenberg.

Neelands, J. (2007). Taming the political; The struggles over recognition in the politics of applied theatre. The Journal of Applied Theatre and Performance, 12(3), 305-317. https://doi.org/10.1080/13569780701560388.

Newby, T., Stepich, D., Lehman, J., \& Russel, J. (2009). Educational Technology for Teaching and Learning. (3 ${ }^{\text {rd }}$ Ed.) (F. Kokavesis trans.). Epikentro. 
Nicholson, H. (2005). Applied drama: The gift of theatre. Palgrave Macmillan.

Pagnes, A. (2020). On Disability Culture, Performing Arts, Social Theatre and the Practice of Beauty. Ephemera Journal, 3(5), 92-127.

Pammenter, D. R. and Prentki, T. (2014). Living beyond our means: meaning beyond our lives. Theatre as Education for Change. Education \& Theatre Magazine, 15, 27-34.

Papadopoulos, S. (2010). Theatre Pedagogy. S.P. Papadopoulos.

Papadopoulos, S. (2014). On the history of Theatre in Education. In Th. Grammatas (Ed.), Theatre in Education. Artistic Expression and Pedagogy, (pp. 147-176). Diadrasi.

Papalexi, M. (2018). Solidarity Theatre for children: like a beloved fairy tale. In K. Sotiriadou and M. Papalexi (Eds.), 20 years of the New World Theatre, 228-243. The New World Editions.

Papaspyrou, I. and Patroni, K. (2014). The Art of Crisis: Theatre Matters (documentary). Art Files Productions.

Patsalidis, S. 2020. Pandemics and Online Theatre. http://savaspatsalidis.blogspot.com/2020/03/online.html

Patsalidis, S. (2013). Theater Interventions. University Studio Press.

Pefanis, G. (2003). Political theatre, theatre in politics and the politics of theatre. In G. Pefanis (Ed.), Buffoon's smile, (pp. 70-71). Aigokeros.

Pefanis, G. (2001). Digital and Theatrical Reality. In G. Pefanis (Ed). Buffoon's smile, (pp. 39-40). Aigokeros.

Pfister. M. (1988). The Theory and Analysis of Drama. Cambridge Universirty Press.

Prendergast, M. and Saxton, J. (2009). Applied Theatre: International case studies and challenges for practice. Intellect Books.

Prentki, T. and Preston, S. (Eds.), (2009). The Applied Theatre Reader. Routledge.

Rodríguez Herrero, P., De la Herrán Gascón, A., \& Cortina Selva, M. (2019). Antecedentes internacionales de la Pedagogía de la muerte. Foro de Educación, 17(26), 259-276. http://dx.doi.org/10.14516/fde.628.

Sakellariou, K. (2015). Educational Drama in Peace Education. [Master thesis, AUTH]. IKEE AUTH Collection. http://ikee.lib.auth.gr/record/286959/files/GRI-2017-18237.pdf.

Samara, T. (2020). Theatre for children in hospitals - The case of the New World Theater team "Solidarity Theatre for Children", [Master thesis, NKUA]. Pergamos collection. https://pergamos.lib.uoa.gr/uoa/dl/object/2898723.

Sanders IV, L. (2018). The Greek dept crisis: A brief history. Deutsche Welle. https://www.dw.com/en/thegreek-debt-crisis-a-brief-history/g-45143673.

Schechner, R. (2011). Performance Theory (N. Kouvarakou trans.) Telethrion.

Sextou, P. (2002). Drama and Theatre in Education in Greece: Past achievements, present demands and future possibilities. The Journal of Applied Theatre and Performance, 7(1), 93-101.

Sextou, P. and Hatzinikolaou, S. (2007). TiE projects on Health Education: "Stefania and the balloon." Education \& Theater Magazine, $8,39-45$.

Smith, H. Greek debt crisis: 'People can't see any light at the end of any tunnel'. The Guardian. https://www.theguardian.com/world/2017/jul/30/greek-debt-crisis-people-cant-see-any-light-at-the-endof-any-tunnel.

Stamati, E. (2019). Documentary Theatre as a theatrical genre. Documentary Theatre as an educational tool, [Master thesis, AUTH]. IKEE AUTH collection. http://ikee.lib.auth.gr/record/306500?ln=el.

Taylor, P. (2009). Applied Theatre: Creating transformative encounters in the community. Heinemann.

Thompson, J. (2003). Applied theatre: Bewilderment and Beyond. Peter Lang. 
Thompson, J. and Schechner, R. (2004). Why 'social theatre'. The Drama Review, 48(3), 11-16.

Tima Charitable Foundation, (2016). Activities 2012-2016. https://www.timafoundation.org/media/news/pdf201711/tima_web_gr.pdf.

Timplalexi, E. (2020). Theatre and Performance Go Massively Online During the COVID-19 Pandemic: Implications and Side Effects. Homo Virtualis, 3(2), 43-54. https://doi.org/10.12681/homvir.25448.

Tzamargias, T. (2010). Sociological aspects of theatre for young audiences, from disesteem to establishment. In Th. Grammatas (Ed.), In Totora land, 445-480. Pataki Editions.

Tziovas, D. (2017). Greece in Crisis: Cultural Politics of Austerity. I. B. Tauris and Co. Ltd.

UNHCR. (2013). Passages. An awareness game confronting the plight of refugees. UNHCR. The UN Refugee Assembly. https://www.unhcr.org/gr/wpcontent/uploads/sites/10/2019/07/PASSAGES_GREEK_FINAL.pdf.

UNHCR. (2014). Experiential learning activities in human rights and refugee rights. UNHCR. The UN Refugee Assembly. https://www.unhcr.org/gr/wpcontent/uploads/sites/10/2019/07/Symbiosis_project_manual_final.pdf.

United Nations General Assembly, (1948). Universal Declaration of Human Rights. https://www.un.org/sites/un2.un.org/files/udhr.pdf.

Vasileiadou, K. (2012). Community Theatre, Theatre for Development and Applied Drama through the examples of Teatro Povero (Italy), Adugna Community Dance Theatre and the application at Etnisk Radgivningcenter Noor (Denmark). [Master thesis]. AUTH IKEE Collection. http://ikee.lib.auth.gr/record/129777?!n=el.

Vosniadou, S. (2006). Children, Schools and Computers. Prospects, problems and suggestions for the most effective use of new technologies in education. Gutenberg.

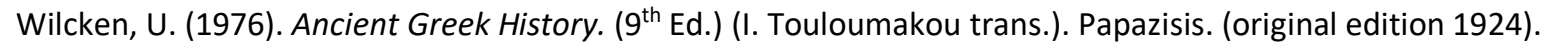

Zervou, N. (2017). Fragments of the European Refugee Crisis: Performing Displacement and the Re-Shaping of Greek Identity. TDR/The Drama Review, 61(2), 32-47. https://doi.org/10.1162/DRAM_a_00646 .

Zoniou, C. (2007). Applied theater in non-formal and informal education: social theater. In A. Tsiaras (Ed.), Theatre in Education: theory and practice, (pp. 71-82), Papazisis.

Zoniou, C. (2016). The contribution of the Theatre of the Oppressed and other dramatic techniques to the development of the intercultural competence of teachers. [Doctoral dissertation, University of Thessaly]. http://thesis.ekt.gr/thesisBookReader/id/40052\#page/1/mode/2up

How to cite this paper:

Gkerlektsi, T. \& Dimaki-Zora, M. (2021). Applied Theatre in Greece: Skipping from Crisis to Crisis. Journal of Literary Education, (5), 144-161.

https://doi.org/10.7203/JLE.5.21537 